\title{
Recovery of pure C-phycoerythrin from a limestone drought tolerant cyanobacterium Nostoc sp. and evaluation of its biological activity
}

Bahareh Nowruzi ${ }^{1}$, Hossein Fahimi ${ }^{2} \&$ Adriana Sturion Lorenzi ${ }^{3}$

1 Department of Biology, Science and Research Branch, Islamic Azad University, Tehran, Iran.

2 Department of Genetics, Faculty of Advanced Science and Technology, Tehran Medical Sciences, Islamic Azad University, Tehran, Iran.

3 Department of Biological Sciences, Luiz de Queiroz College of Agriculture, University of São Paulo (USP), Piracicaba, SP, Brazil.

Correspondence
B. Nowruzi
E-mail: bahareh.nowruzi@srbiau.ac.ir
Received: 2 February 2020

Accepted: 6 July 2020

Published on-line: 6 September 2020

\section{Resumen}

Recuperación de C-ficoeritrina de la cianobacteria tolerante a la sequía Nostoc sp. en caliza y evaluación de su actividad biológica

Se realizó la caracterización de ficoeritrina de la cepa A5 de Nostoc sp., seguida de investigación de su actividad biológica para aplicaciones biotecnológicas. Para la extracción de ficoeritrina, el uso de tampón acetato ( $\mathrm{pH}$ 5.1) produjo $65.04 \mu \mathrm{g} \mathrm{mL}^{-1}$, y se identificó como C-ficoeritrina. Los resultados de su actividad antioxidante sugirieron su acción como un potente eliminador de radicales libres. Además, la C-ficoeritrina de Nostoc mostró una capacidad notable como agente antibacteriano y antifúngico, con estabilidad significativa de hasta 10 días. La glucosa $\left(4 \mathrm{mg} \mathrm{mL}^{-1}\right)$ fue un buen conservante para la C-ficoeritrina a 25 y $4{ }^{\circ} \mathrm{C}$. Se obtuvo por primera vez una C-ficoeritrina estable de Nostoc sp. en condiciones de sequía en piedra caliza, lo que demuestra la necesidad de estudiar microorganismos de ambientes extremos.

Palabras clave: C-ficoeritrina (C-PE); Cianobacterias tolerantes; Nostoc; Actividad biológica.

\begin{abstract}
The phycoerythrin characterization from Nostoc sp. strain A5 was done, followed by investigation of its biological activity for biotechnological applications. For phycoerythrin extraction, the use of acetate buffer $(\mathrm{pH} 5.1)$ resulted in $65.04 \mu \mathrm{g} \mathrm{mL}-1$, and C-phycoerythrin was identified. Results of its antioxidant activity suggested action as a potent free radical scavenger. In addition, Nostoc's Cphycoerythrin showed noteworthy ability for antibacterial and antifungal agents with significant stability up to 10 days. Glucose $(4 \mathrm{mg}$ $\mathrm{mL}^{-1}$ ) was a good preservative for C-phycoerythrin at 25 and $4{ }^{\circ} \mathrm{C}$. A stable C-phycoerythrin from Nostoc sp. was obtained for the first time from limestone drought conditions, showing the need of studying microorganisms from extreme environments.
\end{abstract}

Key words: C-phycoerythrin (C-PE); Tolerant cyanobacteria, Nostoc; Biological activity. 


\section{Introduction}

Cyanobacteria are prokaryotes with oxygenic photosynthetic ability that possess a wide range of coloured components, including carotenoids, chlorophyll and phycobiliproteins. Phycobiliproteins are water-soluble supramolecular protein aggregates involved in light harvesting during photosynthesis and may comprise from 40 to $60 \%$ of the total soluble proteins found in cyanobacteria (Kumar et al. 2014). They are highly diverse in structure and pigment composition, acting as cell protection against photo-oxidative damage under stress conditions (Pandey et al. 2013). Moreover, these colored proteins have considerable importance as natural dyes and possess health-promoting properties in addition to pharmaceutical applications as antimicrobial and antioxidants agents (Liu et al. 2014, Nowruzi et al. 2018a). Antioxidant molecules are important to prevent or delay hepatotoxicity, heart diseases and cancer (Kim et al. 2018). The use of artificial oxidants has reduced due to their potentially carcinogenic nature (Sen et al. 2017). Thus, natural antioxidants are desirable and have been intensively examined (Maurya et al. 2014).

Phycobiliproteins can be divided into three classes based on their spectral properties: phycoerythrin $(\lambda \max \sim 565 \mathrm{~nm})$, phycocyanin $(\lambda \max \sim$ $620 \mathrm{~nm})$, and allophycocyanin $(\lambda \max \sim 650 \mathrm{~nm})$. A fourth phycobiliprotein known as allophycocyanin B $(\lambda \max \sim 670 \mathrm{~nm}$ ) has also been shown to be present in cyanobacteria in low amounts (Kumar et al. 2014). Light absorbed by phycoerythrin is transferred to phycocyanin, then to allophycocyanin and ultimately to chlorophyll during the photosynthetic process (Seo et al. 2013). Phycoerythrins (PEs) are highly sensitive to variations in $\mathrm{pH}$, salt concentration, temperature change, desiccation and light stress (Kesheri \& Sinha 2011).

In vitro processes, such as PEs extraction and purification, difficult its commercial applications. The amount of phycoerythrin can change due to a chromatic adaptation mechanism. Under low light intensity, synthesis of phycoerythrin is promoted to elongate rod structures (Wada et al. 2013). There are typical protocols for PE extraction and purification. Chakdar \& Pabbi (2012) reported that precipitation with $65 \%$ ammonium sulfate resulted in $85.81 \%$ recovery of PE with a purity of 2.81 (OD562/OD280). Ranjitha \& Kaushik
(2005) obtained $85 \%$ recovery of PE from Nostoc muscorum C.Agardh ex Bornet \& Flahault with a purity of 2.89 (A562/A280) using $55 \%$ ammonium sulfate precipitation. Around $80 \%$ recovery of PE content with a purity ratio of around 1.5 was shown for young and old cultures of Phormidium sp. A27DM, Lyngbya sp. A09DM and Halomicronema sp. A32DM after treatment of crude extract with $70 \%$ ammonium sulfate (Parmar et al. 2011). Similarly or higher than reported by Tchernov et al. (1999), Reis et al. (1998) and Parmar et al. (2011), PE purity of 4.95 was achieved by Chakdar \& Pabbi (2012) during chromatographic separation. Moreover, chromatography on DEAE cellulose-52 column gave pure PE (A $562 /$ A 280=8.12) from N. muscorum (Ranjitha \& Kaushik, 2005). Tripathi et al. (2007) shown a PE purity of 5.25 from Lyngbya arboricola Brühl \& Biswas using a procedure involving acetone precipitation and gel filtration in addition to ammonium sulfate precipitation and DEAECellulose column chromatography. However, the recovery $(62.5 \%)$ was not as higher as published by Ranjitha \& Kaushik (2005) and Parmar et al. (2011).

Using different process, phycoerythrin may be used as natural colorants by industries engaged in food and feed production. The potential from soil and fresh water cyanobacteria to produce bioactive compounds has been widely explored (Cadel et al. 2008, Nowruzi et al. 2018b). However, extraction and purification of phycoerythrins from calcareous environments especially that associated with limestone surfaces are underexplored. In the present studied, the Nostoc isolate was obtained from Cretaceous nodular chalk limestone rocks, where the light intensity is extremely high and water is scarce. We hypothesize that the drought tolerant Nostoc sp. A5 produces a stable phycoerythrin (red pigment) to absorb the green light. Hence, this study was conducted in order to understand the properties and degree of stability of PE after extraction and purification from a limestone cyanobacterium and evaluate its biological activities (e.g., antioxidant, antimicrobial activity).

\section{Material and methods}

\section{Cyanobacterial isolation and growth conditions}

Nostoc sp. strain A5 was isolated from a cliff face 
in the North-West Mountains of Khozestan province $\left(34^{\circ} 25^{\prime} 04^{\prime \prime} \mathrm{N}, 47^{\circ} 00^{\prime} 59^{\prime} \mathrm{W}\right)$, Iran, which consists of Cretaceous nodular chalk limestone. In order to obtain a cyanobacterial monoculture, samples were spread into sterile Petri dishes containing solid BG-11 medium (Allen 1968), without a nitrogen source, $\mathrm{pH} 7.1$, and incubated in a growth chamber for two weeks at $28 \pm 1{ }^{\circ} \mathrm{C}$ under constant artificial illumination of 1500-2000 lux. After 14 days of growth, selected colonies were washed three times with deionized water, and transferred to a fresh solid medium. For bacteriafree cultures, colonies were tested for bacterial contamination in dextrose-peptone broth and caseinate-glucose agar media. The selected bacteriafree colony was maintained on different agar slants. After 20 days, the isolate was washed with sterile deionized water, and transferred to $1 \mathrm{~L}$ of freshly prepared liquid $\mathrm{BG} 11_{0}$ medium.

\section{Morphological characterization of the studied strain}

The 10-days-old cyanobacterial strain A5 was examined under a Leica DM750 microscope and morphological descriptions were made according to the classification system devised by Komárek 2013.

\section{Molecular analysis}

Genomic DNA was extracted from living cells using the EZNA SP Plant DNA mini kit (Omega Bio-Tek) according to the manufacturer's instructions. PCR reactions were performed on genomic DNA using the oligonucleotide primers pA (5'AGAGTTTGATCCTGGCTCAG-3') and B23S (5'-CTTCGCCTCTGTGTGCCTAGGT-3') (Stoyanov et al. 2014) that target the 16S rRNA gene sequence. Reactions were cycled with an initial denaturation step at $94{ }^{\circ} \mathrm{C}$ for $5 \mathrm{~min}$, followed by 30 cycles of $30 \mathrm{~s}$ denaturation at $94{ }^{\circ} \mathrm{C}, 30 \mathrm{~s}$ annealing at $55^{\circ} \mathrm{C}$ and $30 \mathrm{~s}$ extension at $72{ }^{\circ} \mathrm{C}$, and final extension step at $72{ }^{\circ} \mathrm{C}$ for $5 \mathrm{~min}$. Amplicons were verified by gel electrophoresis on a $1 \%$ agarose gel stained with ethidium bromide. PCR products were purified using the Geneclean $\mathbb{}$ Turbo kit (Qbiogene, Inc.) prior to sequencing. Sequencing reactions were carried out using the refined PCRs products in a ABI Prism $310 \mathrm{Ge}$ netic Analyzer (Applied Biosystems, Life Technologies). A total volume of $10 \mu \mathrm{L}$ of the PCR master mix included $1 \mu \mathrm{L}$ of forward or reverse primers $(10 \mu \mathrm{M}), 1 \mathrm{x}$ sequencing buffer, $1 \mu \mathrm{L}$ of
Big dye and $100 \eta \mathrm{g}(1 \mu \mathrm{L})$ of DNA. The cycle sequencing reaction was carried out using 25 cycles of $96{ }^{\circ} \mathrm{C}$ for $10 \mathrm{~s}, 50{ }^{\circ} \mathrm{C}$ for $5 \mathrm{~s}$, and $60{ }^{\circ} \mathrm{C}$ for 4 minutes, followed by storage overnight at $4{ }^{\circ} \mathrm{C}$. After the completion of the sequencing reactions, the sequenced products were precipitated by adding $40 \mu \mathrm{L}$ of $0,125 \mathrm{M} \mathrm{NaCl}$ and $2,5 \mathrm{x}$ volume of cold $100 \%$ ethanol, followed by vortexing and centrifugation at $13000 \times \mathrm{g}$ for $10 \mathrm{~min}$ at $4{ }^{\circ} \mathrm{C}$. Once the supernatant was removed, a $5 \mathrm{x}$ volume of $70 \%$ ethanol was added, and the sample centrifuged at $13000 \times \mathrm{g}$ for 5 minutes $\left(4{ }^{\circ} \mathrm{C}\right)$. The supernatant was removed, and the pellet was dried at $37{ }^{\circ} \mathrm{C}$. The purified reaction was resuspended in $12 \mu \mathrm{L}$ of HiDi-formamide, the mixture was spun down, denatured for 2 min at $94^{\circ} \mathrm{C}$ and subjected to sequencing. The runtime for each reaction was 45 min with a running voltage of $15 \mathrm{kV}$ at a temperature of $50{ }^{\circ} \mathrm{C}$ and the polymer used was POP$6^{\text {TM }}$ (Applied Biosystems, Life Technologies). The 16S rRNA gene sequences obtained in this study was used to construct a consensus sequence in BioEdit version 7.0. Positions with gaps, as well as undetermined and ambiguous sequences were removed. BLAST searches (http://www.ncbi.nlm. nih.gov/BLAST) of the partial 16S rRNA gene sequence were used to identify similar sequences available in the GenBank database of NCBI (National Center for Biotechnology Information).

\section{Chemicals}

All chemicals and protein molecular weight marker used in this study were of analytical grade, purchased from the Hi-Media, Merck and Sigma manufacturers. All buffers and reagents used were prepared in double distilled water.

\section{Extraction and estimation of phycobilipro- teins}

Phycoerythrin (PE) were extracted from $500 \mathrm{~mL}$ of homogenized log phase (14 days old) culture after centrifuged at 4,000 rpm to obtain a pellet. The pellet was suspended in $100 \mathrm{~mL}$ of $20 \mathrm{mM}$ acetate buffer ( $\mathrm{pH}$ 5.1). Extraction was carried out by repeated freezing $\left(-20^{\circ} \mathrm{C}\right)$ and thawing (room temperature) method for 4 days until cell biomass became dark purple. Cell debris was removed by centrifugation at $5,000 \mathrm{rpm}$ for $10 \mathrm{~min}$, and a crude extract was obtained. In addition to acetate buffer ( $\mathrm{pH}$ 5.1; 0.1 M), optimization of PE extraction was tested using different buffers [citrate buffer $(\mathrm{pH} 5.0 ; 0.1 \mathrm{M})$; carbonate buffer $(\mathrm{pH} 9.6 ; 0.1$ 
$\mathrm{M})$; tris buffer $(\mathrm{pH} 7.2 ; 0.05 \mathrm{M})$, and sodium phosphate buffer $(\mathrm{pH} 7.0 ; 0.1 \mathrm{M})]$ as published previously by Afreen \& Fatma (2018).

\section{Purification}

Purification was carried out according to Afreen \& Fatma (2018). Solid ammonium sulphate was added to the crude extract slowly for achieving $65 \%$ saturation by continuous stirring. The resulting solution was allowed to stand for $12 \mathrm{~h}$ under cold room, and centrifuged at $4,500 \times \mathrm{g}$ for $10 \mathrm{~min}$. The pellets were re-suspended in a small volume of $50 \mathrm{mM}$ acetic acid-sodium acetate buffer $(\mathrm{pH}$ 7.1 ), and dialyzed overnight. The extract was recovered from the dialysis membrane and filtered through $0.45 \mu \mathrm{m}$ filter (Chakdar \& Pabbi 2012, Tiwari et al. 2015).

DEAE-Cellulose 11 from Sisco Research Laboratory (SRL) was used for anion exchange chromatography. A column of $30 \mathrm{~cm} \times 2 \mathrm{~cm}$ dimension was prepared for purifying the PE protein. The column was equilibrated with $150 \mathrm{~mL}$ of acetate buffer (pH 5.1) and $10 \mathrm{~mL}$ of dialysed, and filtered sample was placed on the top of the DEAE-cellulose column with the help of a syringe. Acetate buffer $(50 \mathrm{~mL}, \mathrm{pH} 5.1)$ was applied to the column to wash out any unbound protein. A linear gradient of acetate buffer with $\mathrm{pH}$ ranging from 3.76 to 5.1 was used to develop the column and eluates were collected in $5 \mathrm{~mL}$ fractions. Flow rate was kept at $20 \mathrm{mLh}^{-1}$ (Román et al. 2002, García-Falcón \& Simal-Gándara 2005).

SDS-PAGE was carried out in a vertical slab gel apparatus (Miniprotean III, Bio-Rad) according to Zhao et al. (2013) using a $16.5 \%$ polyacrylamide slab gel containing $0.1 \%(\mathrm{w} / \mathrm{v})$ SDS with a stacking gel of $4 \%$ polyacrylamide. Samples were pre-incubated with $4 \%$ (w/v) SDS, $12 \%$ (v/ v) glycerol, $2 \%(\mathrm{v} / \mathrm{v})$ mercaptoethanol, $0.025 \%$ (w/v) bromophenol blue, and $50 \mathrm{mM}$ Tris, $\mathrm{pH} 6.8$, for about $5 \mathrm{~min}$ at $95{ }^{\circ} \mathrm{C}$. Gels were run at room temperature, visualized by staining for $30 \mathrm{~min}$ with $0.1 \%(\mathrm{w} / \mathrm{v})$ Coomassie Brilliant Blue R-250, $40 \%$ methanol (v/v) with $7 \%(\mathrm{v} / \mathrm{v})$ acetic acid, and de-stained in dilute acetic acid. The molecular weight of the purified protein was determined by running a Novex Sharp pre-stained protein marker along with the sample.

The absorption spectrum was determined by scanning the sample in a range of 300-750 nm wavelengths by Specord 200 spectrophotometer
(Analytik Jena, Germany).

The amounts of PE (phycoerythrin), PC (phycocyanin) and APC (allophycocyanin) in the different extracts and biliprotein (PBPs) containing solutions were calculated from measurements of the absorbance at 565, 620 and $650 \mathrm{~nm}$ using the following equations Román (2002):

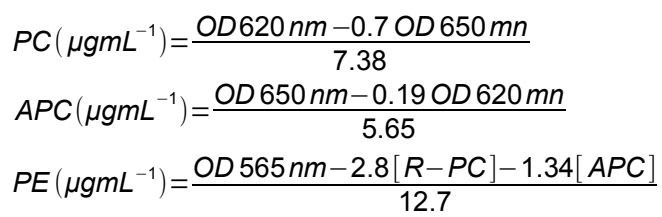

Purity of PE was calculated at each step as purity ratio (A565/A280). Absorbance at $565 \mathrm{~nm}$ and $280 \mathrm{~nm}$ indicated the concentration of PE and proteins, respectively.

These equations were established by using the simultaneous equations of Bennett \& Bogorad (1973) and the extinction coefficients from Bryant et al. (1979).

\section{Effect of temperature and preservatives on the optical properties of purified PE}

Stability of purified PE $\left(710 \mu \mathrm{g} \mathrm{mL}^{-1}\right)$ was obtained by measuring loss (\%) of PE without adding additives and also with sucrose and glucose as preservatives $\left(4 \mathrm{mg} \mathrm{mL}^{-1}\right)$ at different temperatures $\left(25,30,35,40,45,4\right.$ and $\left.-20^{\circ} \mathrm{C}\right)$ by recording its absorption spectrum for 10 hours (Setyoningrum \& Nur 2015, Gonzalez-Ramirez et al. 2014, Rastogi et al. 2015).

\section{Biological activity of purified PE}

Evaluation of antifungal and antibacterial activity

The purified PE $\left(710 \mu \mathrm{gmL}^{-1}\right)$ was tested for its antifungal and antibacterial activities using the paper disk diffusion method. Muller Hinton Agar (MHA) $(25 \mathrm{~mL})$ and Saubouraud's dextrose agar were used for antibacterial and antifungal activities, respectively. Agar plates were inoculated with a standardized quantity of suspension containing $1.5 \times 10^{8} \mathrm{CFUmL}^{-1}$ bacteria corresponding to 0.5 MacFarland standard according to Wikler et al. (2006). Final inoculums density from $0.5 \times 10^{5}$ to $2.5 \times 10^{5} \mathrm{CFUmL}^{-1}$ Candida albicans (C.P. Robin) Berkhout and $0.4 \times 10^{4}-5 \times 10^{4} \mathrm{CFUmL}^{-1}$ Aspergillus niger P.E.L. van Tieghem were calibrated by using a hemocytometer cell counting chamber. Plates were incubated overnight at $37^{\circ} \mathrm{C}$ for $18-24 \mathrm{~h}$ (bacteria) and at $35{ }^{\circ} \mathrm{C}$ for $24-48 \mathrm{~h}$ (fungi). The microorganisms used in assays were 
obtained from the Iranian Research Organization for Science and Technology (IROST). Three gram-positive bacteria Staphylococcus aureus Rosenbach (PTCC 1112), Bacillus subtilis (Ehrenberg) Cohn (PTCC 1023), Bacillus cereus Frankland \& Frankland (PTCC 1015), three Gram-negative bacteria Escherichia coli (Escherich) (PTCC 1047), Pseudomonas aeruginosa (Schroeter) Migula (PTCC 1310), Salmonella typhimurium (ex Kauffmann \& Edwards) Le Minor \& Popoff (PTCC 1609), a yeast Candida albicans (ATCC 10231) and a phytopathogenic fungus Aspergillus niger (ATCC 16404) were employed in the study. The diameter of the zones with complete inhibition of growth was measured to the nearest millimeters using a ruler and expressed in $\mathrm{mm}$. All the tests were performed under sterile conditions and repeated three times. The antibacterial agents tetracycline $(30 \mu \mathrm{g})$ and gentamicin $(10 \mu \mathrm{g})$, and antifungal agent nystatin $(10 \mu \mathrm{g})$ were included in the assays as positive standard antibiotic control (Espinel-Ingroff 2007).

For determination of stability of purified PE, filter discs were stored in Petri dishes at room temperature for 10 days and the antibiogram bioassays were performed again (Nowruzi et al. 2012).

Bioassays for additional evaluation of results taking into consideration the quantity of compound with antimicrobial activity by minimum inhibitory concentration (MIC) of $\mu \mathrm{g} \mathrm{mL}^{-1}$ were carried out according to the standard reference method (Wayne, 1999).

Minimum inhibitory concentrations of purified PE were determined by the broth dilution method. The MIC for fungi was performed in 10 tubes $(16 \times 160 \mathrm{~mm})$ containing $1 \mathrm{~mL}$ Saubouraud's dextrose broth with $1 \mathrm{~mL}$ of dilutions of purified $\mathrm{PE}$ and $100 \mu \mathrm{L}$ of suspension containing $10^{4}$ spore $\mathrm{mL}^{-1}$ of fungi cultures. The required concentration of the purified PE was dissolved in $1 \mathrm{~mL}$ of Saubouraud's dextrose broth and diluted to serial twofold dilution ranging from 250 to $0.97 \mu \mathrm{g} \mathrm{mL}{ }^{-1}$. The tubes of 11 and 12 were considered as controls containing $1 \mathrm{~mL}$ Saubouraud's dextrose broth with $1 \mathrm{~mL}$ of purified PE $\left(500 \mathrm{mg} \mathrm{mL}^{-1}\right)$ and $1 \mathrm{~mL}$ Saubouraud's dextrose broth with $100 \mu \mathrm{L}$ of fungi cultures, respectively. Tubes were incubated at $27{ }^{\circ} \mathrm{C}$ for 2 days. Fungi growth in tubes was assessed visually. One (1) $\mu \mathrm{L}$ of supposed tested broth was placed on the sterile Saubouraud's dextrose agar as the lowest concentration of the com- pound inhibiting the visual growth of the test cultures on the agar plate. If there was no visible growth, MIC was considered as minimum bactericidal concentration (MBC). For bacteria, MIC was determined according to the standard CLSI guidelines. Mueller-Hinton agar plates with active principle $\left(250-0.97 \mu \mathrm{g} \mathrm{mL}^{-1}\right)$ were spotted with 2 $\mu \mathrm{L}$ bacterial inocula $\left(10^{7} \mathrm{CFU} \mathrm{mL}^{-1}\right)$ and incubated at $37^{\circ} \mathrm{C}$ for $20 \mathrm{~h}$. MIC was determined as the lowest concentration of purified PE resulting in complete inhibition of fungi and bacteria growth after the incubation time. There were three replicates per assay and each test was repeated at least twice.

The data of all the parameters were statistically analyzed using the one-way ANOVA with $95 \%$ confidence limits $(\mathrm{p}<0.05)$ and results expressed as mean $\pm \mathrm{SE}$.

\section{Antioxidant activity of purified PE}

\section{2, 2 Diphenyl-1-Dipicrylhydrazyl (DPPH) assay}

This test was conducted following the method described by Shanab et al. (2012) with modifications. An amount of $710 \mu \mathrm{gmL}^{-1}$ purified PE was mixed with $1 \mathrm{~mL}$ of DPPH reagent. After incubating for $30 \mathrm{~min}$ in the dark at room temperature, the absorbance was measured at $517 \mathrm{~nm}$. Ascorbic acid $\left(100 \mu \mathrm{gmL}^{-1}\right)$ was used as positive control.

Activity (\%) $=A c-A t / A c \times 100$

Where At was the absorbance of sample, and Ac the absorbance of DPPH.

\section{ABTS assay}

ABTS + radicals $(7 \mathrm{mM})$ were produced by adding potassium persulphate $(2.45 \mathrm{mM})$ in the dark for 12-16 $\mathrm{h}$. The resulting solution was diluted with ethanol up to an absorbance of 0.5 at $734 \mathrm{~nm}$. An aliquot of $3 \mathrm{~mL}$ of ABTS + solution was added to $50 \mu \mathrm{L}$ of the PE sample $\left(710 \mu \mathrm{gmL}^{-1}\right)$ and standards, and the absorbance was recorded at $734 \mathrm{~nm}$ against ethanol as blank (Re, 1999). ABTS+ solution was taken as positive control and BHT as standard.

Activity $(\%)=A c-A t / A c \times 100$

Where At was the absorbance of sample, and Ac the absorbance of ABTS.

Superoxide anion radical scavenging activity assay

Superoxide anion radical (SOR) assay followed as described by Afreen \& Fatma (2018). Reaction mixture was prepared by adding $0.2 \mathrm{~mL}$ methio- 
nine (200 mM), $1.5 \mathrm{~mL} \mathrm{Na}_{2} \mathrm{CO}_{3}(1 \mathrm{M}), 0.1 \mathrm{~mL}$ nitro blue tetrazolium, $0.1 \mathrm{~mL}$ riboflavin $(60 \mu \mathrm{M})$; $0.1 \mathrm{~mL}$ EDTA $(3 \mathrm{mM})$ and $0.2 \mathrm{~mL}$ distilled water. The mixture was kept in the presence of light for $1 \mathrm{~h}$ during which changed its color to blue. A volume of $0.88 \mathrm{~mL}$ Tris- $\mathrm{HCl}(50 \mathrm{mM})$ was added to $0.2 \mathrm{~mL}$ of the PE sample $\left(710 \mu \mathrm{g} \mathrm{mL}^{-1}\right)$ including standard, and incubated in a water bath at $25{ }^{\circ} \mathrm{C}$ for $10 \mathrm{~min}$. A volume of $2.2 \mathrm{~mL}$ of the reaction mixture was added to test tubes and the absorbance was measured at $560 \mathrm{~nm}$ against distilled water as blank, reaction mixture as positive control and vitamin $\mathrm{C}$ as standard (1 $\mathrm{mM}$ stock). The percentage of the SOR scavenging was calculated using the following equation:

Superoxide anion radical scavenging effect $(\%)=(A 0-A 1 / A 0) \times 100$

Where $\mathrm{A} 0$ was the absorbance of the control, and A1 was the absorbance of the test sample. The actual decrease in absorption induced by the test was compared with the positive control. IC $_{50}$ values were determined by plotting the graph of $\mathrm{PE}$ concentration versus the percentage of scavenging free radicals.

\section{Nitric oxide (NO) scavenging activity}

The nitric oxide radical scavenging activity was measured by using Griess reagent according to Kamble et al. (2013). Volumes of 50, 100, 150, 200 and $250 \mu \mathrm{L}$ of purified PE $\left(710 \mu \mathrm{g} \mathrm{mL}^{-1}\right)$ and $500 \mu \mathrm{L}$ of standard (vitamin $\mathrm{C} 1 \mathrm{mg} \mathrm{mL}^{-1}$ ) were taken and diluted up to $1.5 \mathrm{~mL}$ with distilled water in test tubes. A volume of $1.5 \mathrm{~mL}$ of $10 \mathrm{mM}$ sodium nitroprusside was added to all tubes and incubated for $150 \mathrm{~min}$ at $25^{\circ} \mathrm{C}$. After incubation, $1.5 \mathrm{~mL}$ of the reaction mixture was transferred to the new tubes and $1.5 \mathrm{~mL}$ Griess reagent $(1 \%$ sulphanilamide, $2 \%$ orthophosphoric acid, $0.1 \%$ NEDD) was added to all tubes. O.D. was taken at $545 \mathrm{~nm}$. Vitamin $\mathrm{C}$ was used as positive control and decrease in absorbance indicates high scavenging activity. The experiments were performed in triplicates and percent scavenging activity was calculated as follows:

$$
\text { Scavenging }(\%)=\frac{\text { Abs of control }- \text { Abs of the test }}{A b s \text { of control }} \times 100
$$

\section{Results}

\section{Morphological and molecular characteriza- tion}

Nostoc sp. strain A5 was able to grow rapidly on liquid media culture, and changed the color from light brown to dark brown under laboratory conditions (Figs. 1A-C). Microscopic observation showed brownish or dark-colored trichomes. Vegetative cells similar in form, cylindrical, 3.5-4.0 $\mu \mathrm{m}$ wide, $7.0-11.0 \mu \mathrm{m}$ in length, brownish. Heterocytes somewhat spherical or oblong, 5.0-6.5 $\mu \mathrm{m}$ wide, $6.0-12.5 \mu \mathrm{m}$ long. Akinetes were ellipsoidal to oblong, $5.0-5.5 \mu \mathrm{m}$ wide, $10.0-12.0 \mu \mathrm{m}$ long. The size of the spherical colonies ranged from 0.5 to $5.0 \mathrm{~mm}$. The unicyanobacterial culture and dry type material were deposited into $\mathrm{AL}$ BORZ herbarium and Cyanobacteria Culture Collection (CCC) of Science and Research Branch, Islamic Azad University, Tehran, respectively. The studied strain was further characterized based on the 16S rRNA gene sequence, and registered under the DDBJ accession number MG385057.
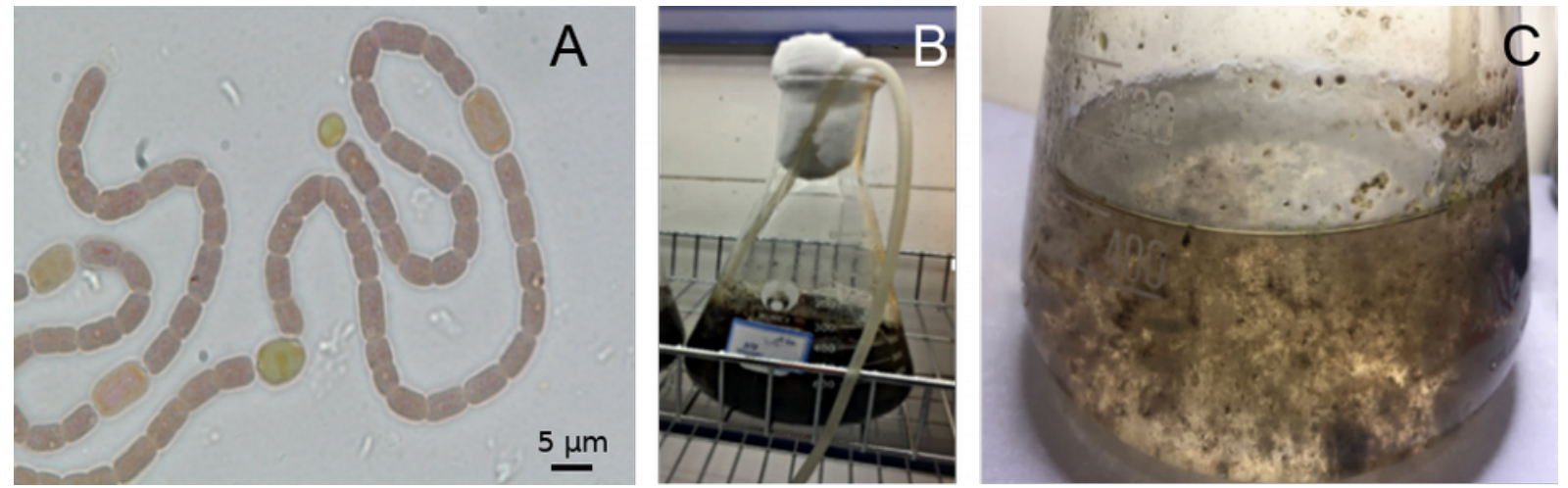

Figura 1. Microscopía de campo brillante con células vegetativas y heterocitos intercalares y terminales. A: colonias macroscópicas de color marrón oscuro en cultivos de medios líquidos $(\mathbf{B}, \mathbf{C})$. Barra: $5 \mu \mathrm{m}$

Figure 1. Bright field microscopy with vegetative cells and intercalary and terminal heterocytes. A: macroscopic dark brown colonies in liquid media cultures $(\mathbf{B}, \mathbf{C})$. Bar: $5 \mu \mathrm{m}$. 


\section{Extraction, purification and characterization of PE}

PE extraction from Nostoc sp. A5 was optimized for its maximum recovery and acetate buffer $(\mathrm{pH}$ 5.1) was found to generate better result, extracting $65.04 \mu \mathrm{gmL}^{-1}$ by freezing and thawing method (Table 1). Purity ratio is an indicator of the purification degree in which 0.7 is considered as food grade, 3.9 as reactive grade and greater than 4.0 as analytical grade (Delgado-Vargas \& ParedesLópez 2002). As revealed from the high final purity (OD565/OD280=1.5), PE extraction using acetate buffer $(\mathrm{pH}$ 5.1) was efficient to result in high purity of PE in comparison to other buffers (Table 1). For this reason, further PE extraction was done in acetate buffer only.

\begin{tabular}{|c|c|c|c|c|}
\hline & Steps & $\begin{array}{l}\text { Vol. } \\
(\mathrm{mL})\end{array}$ & $\begin{array}{c}\mathrm{PE} \\
\left(\mu \mathrm{gmL}^{-1}\right)\end{array}$ & $\begin{array}{c}\text { Purity of PE } \\
\text { (OD565/OD280) }\end{array}$ \\
\hline \multirow{5}{*}{$\begin{array}{l}\text { Crude } \\
\text { extract }\end{array}$} & Acetate (pH 5.1) & \multirow{5}{*}{100} & 65.04 & 1.5 \\
\hline & Carbonate (pH 9.6) & & 55.10 & 0.9 \\
\hline & Citrate $(\mathrm{pH} 5.0)$ & & 34.06 & 0.5 \\
\hline & Sodium phosphate $(\mathrm{pH} 7)$ & & 20.04 & 0.15 \\
\hline & Tris $(\mathrm{pH} \mathrm{7.2)}$ & & 8.3 & 0.03 \\
\hline \multicolumn{2}{|c|}{ Ammonium Sulfate precipitation } & 10 & 532 & 4.82 \\
\hline \multicolumn{2}{|c|}{ Dialysis } & 10 & 550 & 4.97 \\
\hline \multicolumn{2}{|c|}{$\begin{array}{l}\text { DEAE-Cellulose column } \\
\text { chromatography }\end{array}$} & 5 & 710 & 6.22 \\
\hline
\end{tabular}

Tabla 1. Purificación gradual de PE de Nostoc sp. A5.

Table 1. Stepwise purification of PE from Nostoc sp. A5.

At each purification step, concentration and purity of PE were checked as shown in table 1 . During successive steps of purification, involving ammonium sulfate precipitation followed by a single step anion exchange chromatography using DEAE cellulose-11 column and acetate buffer, the purity ratio increased from 1.5 up to 6.22 . It was found to be enhanced after each purification step (Fig. 2, step I to step IV).

From crude extract to purified PE, purity was increased by almost four times, which showed the efficiency of the method to obtain high purity phycoerythrin. According to the absorption spectra, PE have categorized into three types: (i) BPE, $\lambda$ max $\sim 540-560 \mathrm{~nm}$, shoulder at $\sim 495 \mathrm{~nm}$; (ii) R-PE, $\lambda$ max $\sim 565,545$ and $495 \mathrm{~nm}$, and (iii) C-PE, $\lambda$ max $\sim 563 / 543$ and $492 \mathrm{~nm}$ (Sun et al. 2009). Absorption spectra of purified PE showed maximum absorption at $565 \mathrm{~nm}$, which clearly indicates that the purified phycoerythrin is of CPE nature (Fig. 2, step I to step IV). Precipitation of phycobiliproteins with $65 \%$ saturation of

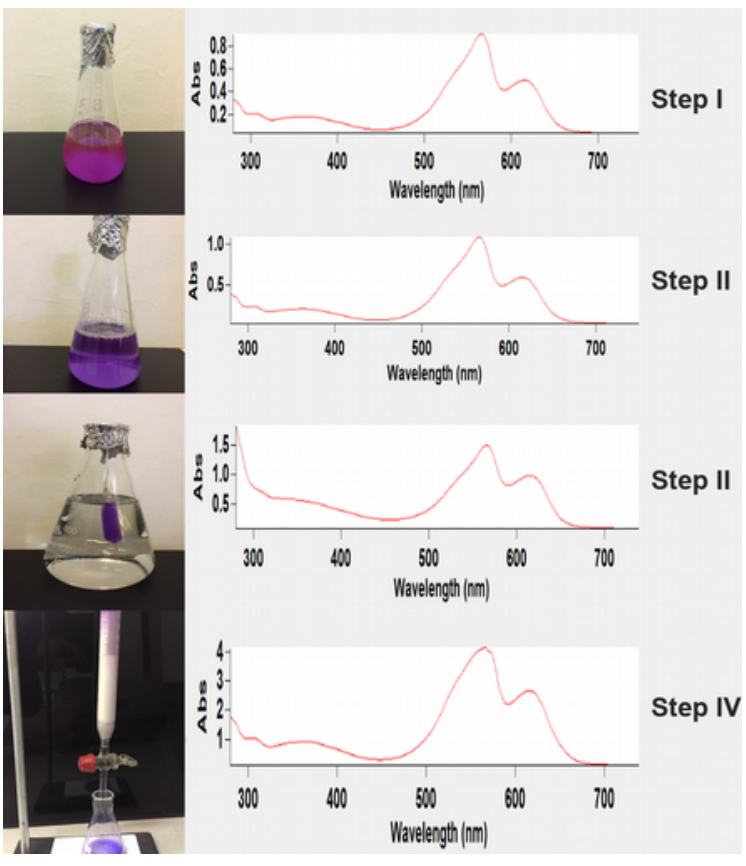

Figura 2. Preparación y espectros de absorbancia de PE purificado en varias etapas de purificación. Paso I, preparación del extracto crudo; Paso II, precipitación con sulfato de amonio, Paso III, diálisis; PASO IV, cromatografía de intercambio aniónico.

Figure 2. Preparation and absorbance spectra of purified PE at various stages of purification. Step I, preparation of the crude extract; Step II, ammonium sulfate precipitation, Step III, dialysis; STEP IV, anion exchange chromatography.

ammonium sulfate resulted in a purity of 4.82 , although no significant increase in purity was observed after dialysis (4.97) (Table 1). During the chromatographic separation, it was possible to obtain a different fraction of phycobiliproteins blue, pink and violet. C-PE with maximum purity $(\mathrm{OD} 565 / \mathrm{OD} 280=6.22)$ and concentration of 710 $\mu \mathrm{g} / \mathrm{mL}$ was eluted as a pinkish-violet-color solution at pH 3.9 (Figs. 3A, B; Table 1). The SDSPAGE analysis of the purified $\mathrm{PE}(\mathrm{pH}$ 3.9) revealed two bands of $\sim 15 \mathrm{KDa}$ and $17 \mathrm{KDa}$ corresponding to $\alpha$ and $\beta$ subunits, respectively (Fig. 4).

\section{Effects of different temperatures and preservatives on PE obtained from Nostoc sp. A5}

The absorption spectrum was recorded with or without preservative at 25, 30, 35, 40, 45, 4 and $20{ }^{\circ} \mathrm{C}$. The visible absorption spectra of C-PE showed that the loss of color was slightly lower at $45{ }^{\circ} \mathrm{C}$ and very high at $-20{ }^{\circ} \mathrm{C}$ in ten hours (Fig. $5 \mathrm{~A})$. The maximum rate of decrease was found with the presence of sucrose (Fig. 5B) at 35, 40 and $45^{\circ} \mathrm{C}$, while there was drastic change at $45^{\circ} \mathrm{C}$ 


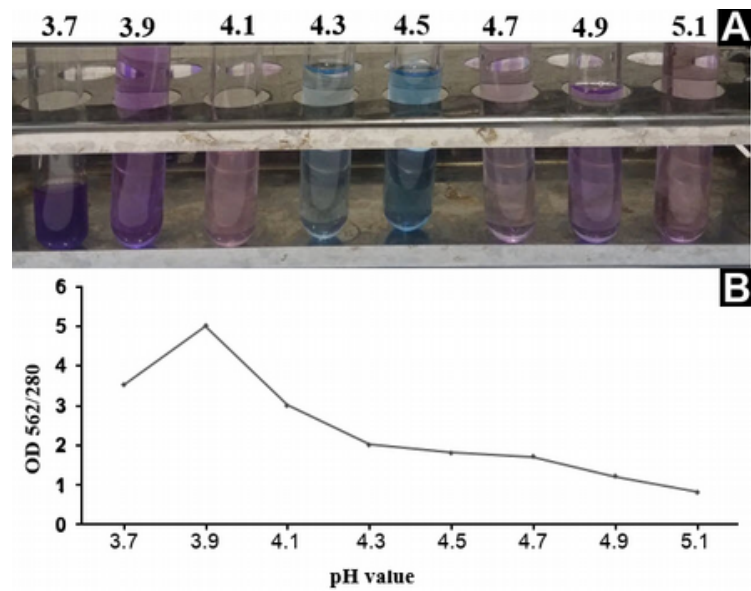

Figura 3. A: Eluados coloreados obtenidos durante el desarrollo de la columna a diferentes $\mathrm{pH}$; B: Propiedades ópticas de PE en el rango de $\mathrm{pH}(\mathrm{b})$.

Figure 3. A: Coloured eluates obtained during developing the column at different $\mathrm{pH}$; B: Optical properties of $\mathrm{PE}$ in the $\mathrm{pH}$ range.

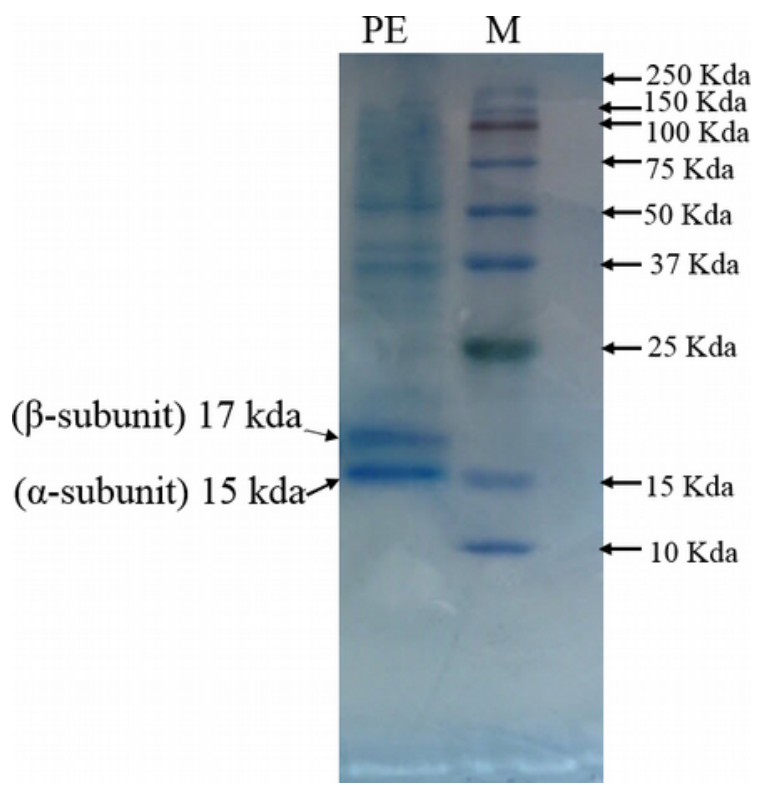

Figura 4. Análisis de SDS-PAGE de ficoeritrina purificada. M: marcador de peso molecular de la proteína, PE - ficoeritrina purificada.

Figure 4. The SDS-PAGE analysis of purified phycoerythrin. M Protein molecular weight marker, PE- purified phycoerythrin.

with glucose (Fig. 5C). In some cases, the use of additives increased the absorbance of C-PE. For instance, with sucrose at 25 and $4{ }^{\circ} \mathrm{C}$, the absorbance increased very slowly, while the highest increase of slop was found with glucose.

\section{Biological activity of purified PE}

Antibacterial and antifungal activities were demonstrated in all of the tested Gram positive and Gram negative bacteria and fungi. It was found that PE had the strongest inhibitory effect
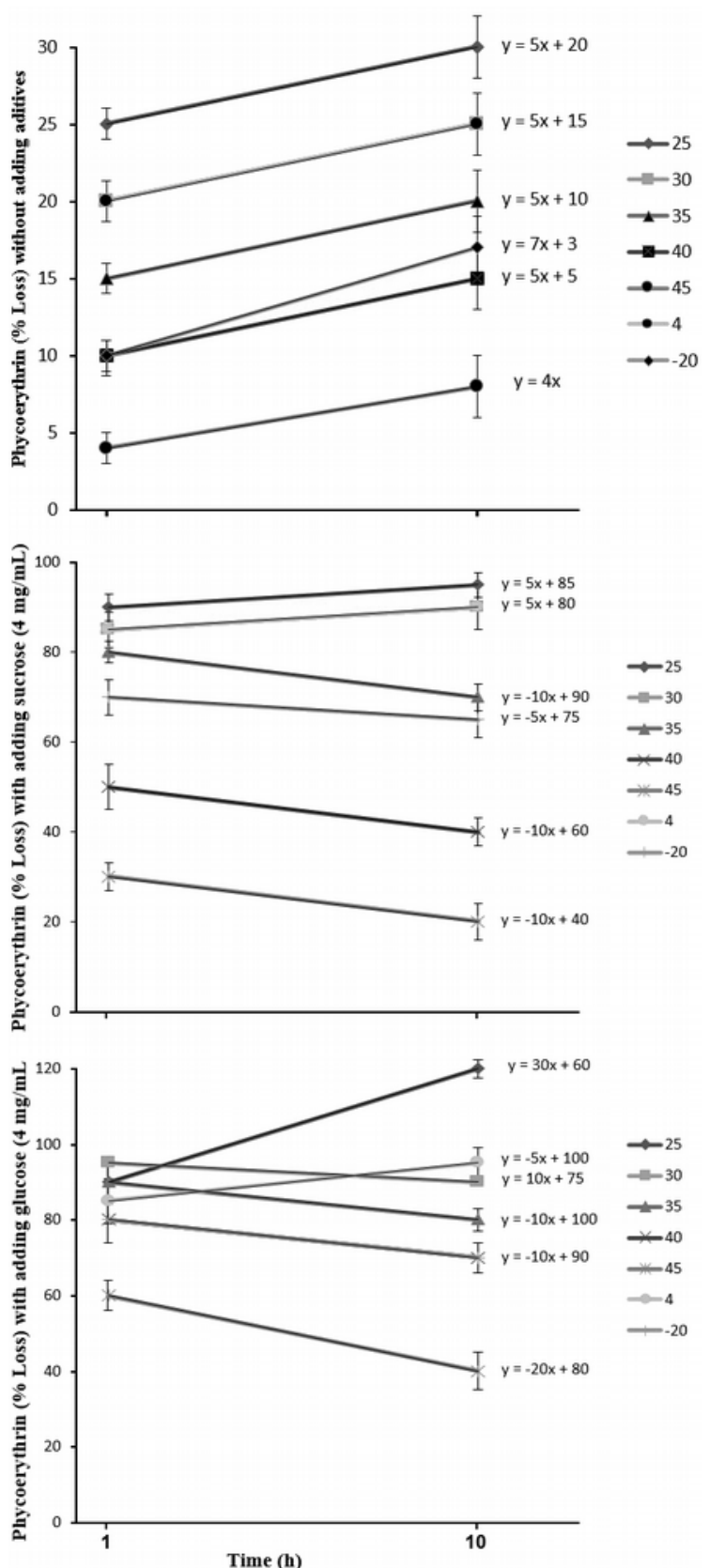

Figura 5. A: Pérdida (\%) en la cantidad de PE puro obtenido de Nostoc sp. A5 sin agregar aditivos. Presencia de sacarosa (B) y glucosa (C) para evaluar sus efectos conservantes sobre las propiedades ópticas de C-PE a diferentes temperaturas $(25,30$, $35,40,45,4$ y $-20^{\circ} \mathrm{C}$ ) en diez horas.

Figure 5. A: Loss (\%) in the amount of pure PE obtained from Nostoc sp. A5 without adding additives. Presence of sucrose (B) and glucose (D) to evaluate their preservative effects on the optical properties of C-PE at different temperatures $(25,30,35$, $40,45,4$ and $-20^{\circ} \mathrm{C}$ ) in ten hours.

against Staphylococcus aureus and Aspergillus niger (Tables 2 and 3, respectively).

The antimicrobial activity produced by purified PE measured by minimum inhibitory concentration has shown in tables 4 and 5 for bacteria and fungi, respectively. The results indicated that 
the MICs of purified PE was $3.9 \mu \mathrm{g} \mathrm{mL}^{-1}$ against Bacillus subtilis and Pseudomonas aeruginosa, whereas it was more than $7.81 \mu \mathrm{g} \mathrm{mL} L^{-1}$ against Bacillus cereus, Escherichia coli, Staphylococcus aureus and Salmonella typhimurium (Table 4). Furthermore, results demonstrated that the MICs of the purified PE was $3.9 \mu \mathrm{g} \mathrm{mL}^{-1}$ against Candida albicans, whereas it was $7.81 \mu \mathrm{g} \mathrm{mL}$ against Aspergillus niger (Table 5).

Statistical analysis revealed there was no significant decrease in the inhibitory effect of the biomass after 10 days (Tables 2 and 3). As it is

\begin{tabular}{lcc}
\hline Microorganism & $\begin{array}{c}\mathbf{P E}=\mathbf{7 1 0} \\
\left(\boldsymbol{\mu g ~ ~ ^ { - 1 } )}\right)\end{array}$ & After 10 days \\
\hline $\begin{array}{l}\text { Bacillus subtilis } \\
\text { (PTCC 1023) }\end{array}$ & $10.9 \pm 0.16$ & $9.9 \pm 0.46$ \\
\hline $\begin{array}{l}\text { Bacillus cereus } \\
\text { (PTCC 1015) }\end{array}$ & $12.16 \pm 0.44$ & $11.5 \pm 0.18$ \\
\hline $\begin{array}{l}\text { Escherichia coli } \\
\text { (PTCC 1047) }\end{array}$ & $10.3 \pm 0.88$ & $9.56 \pm 0.37$ \\
\hline $\begin{array}{l}\text { Staphylococcus aureus } \\
\text { (PTCC 1112) }\end{array}$ & $12.33 \pm 0.33$ & $12 \pm 0.15$ \\
\hline $\begin{array}{l}\text { Pseudomonas aeruginosa } \\
\text { (PTCC 1310) }\end{array}$ & $9.83 \pm 0.44$ & $9 \pm 0.2$ \\
\hline $\begin{array}{l}\text { Salmonella typhimurium } \\
\text { (PTCC 1609) }\end{array}$ & $12.5 \pm 0.76$ & $12 \pm 0.49$ \\
\hline
\end{tabular}

Tabla 2. Actividad antibacteriana del PE purificado presentado por diámetro de zona de inhibición (mm). Resultados son medias \pm error estándar.

Table 2. Antibacterial activity of the purified PE presented by inhibition zone diameter $(\mathrm{mm})$. Results are means $\pm \mathrm{SE}$. illustrated in the results section, some variations were observed from experiment to experiment and it became clear that a given bioactive isolate did not necessarily show clearing at all the times.

\section{Antioxidant activity of purified PE}

Free radical scavenging potential of Nostoc sp. A5 $\mathrm{PE}$ in all of the four methods was found to be concentration dependent. $\mathrm{IC}_{50}$ value in $\mathrm{DPPH}$ method was $0.038 \mathrm{mg} \mathrm{mL}^{-1}$ for $\mathrm{PE}$ and $0.032 \mathrm{mg} \mathrm{mL}^{-1}$ for ascorbic acid (vitamin-C) that was used as standard (Fig. 6A). For ABTS method, $\mathrm{IC}_{50}$ values were

\begin{tabular}{|c|c|c|}
\hline Microorganism & $\begin{array}{l}P E=710 \\
\left.\mu g \mathrm{~mL}^{-1}\right)\end{array}$ & After 10 days \\
\hline $\begin{array}{l}\text { Aspergillus niger } \\
\text { (ATCC 16404) }\end{array}$ & $13.55 \pm 0.18$ & $10.9 \pm 0.1$ \\
\hline $\begin{array}{l}\text { Candida albicans } \\
\text { (ATCC 10231) }\end{array}$ & $12.33 \pm 0.37$ & $10.5 \pm 0.18$ \\
\hline
\end{tabular}

Tabla 3. Actividad antifúngica del PE purificado presentado por el diámetro de la zona de inhibición (mm). Resultados son medias \pm error estándar.

Table. 3. Antifungal activity of the purified PE presented by inhibition zone diameter $(\mathrm{mm})$. Results are means \pm SE.

\begin{tabular}{|c|c|c|c|c|c|c|c|c|c|c|}
\hline Microorganism & 250 & 125 & 62.5 & 31.25 & 15.62 & 7.81 & 3.9 & 1.95 & 0.97 & MIC \\
\hline $\begin{array}{l}\text { Bacillus subtilis } \\
\text { (PTCC 1023) }\end{array}$ & - & - & - & - & - & - & - & + & + & 3.9 \\
\hline $\begin{array}{l}\text { Bacillus cereus } \\
\text { (PTCC 1015) }\end{array}$ & - & - & - & - & - & - & + & + & + & 7.81 \\
\hline $\begin{array}{l}\text { Escherichia coli } \\
\text { (PTCC 1047) }\end{array}$ & - & - & - & - & - & - & + & + & + & 7.81 \\
\hline $\begin{array}{l}\text { Staphylococcus aureus } \\
\text { (PTCC 1112) }\end{array}$ & - & - & - & - & - & - & + & + & + & 7.81 \\
\hline $\begin{array}{l}\text { Pseudomonas aeruginosa } \\
\text { (PTCC 1310) }\end{array}$ & - & - & - & - & - & - & - & + & + & 3.9 \\
\hline $\begin{array}{l}\text { Salmonella typhimurium } \\
\text { (PTCC 1609) }\end{array}$ & - & - & - & - & - & - & + & + & + & 7.81 \\
\hline
\end{tabular}

Tabla 4. Concentración inhibitoria mínima (CIM) del PE purificado. (-) Sin crecimiento; (+) Crecimiento. Concentración en $\mu \mathrm{g} / \mathrm{mL}$. Table 4. Minimum Inhibitory Concentration (MIC) of the purified PE. (-) No growth observed; (+) Growth observed. Concentration of extracts in $\mu \mathrm{g} / \mathrm{mL}$.

\begin{tabular}{lcccccccccc}
\hline Microorganism & 250 & $\mathbf{1 2 5}$ & $\mathbf{6 2 . 5}$ & $\mathbf{3 1 . 2 5}$ & $\mathbf{1 5 . 6 2}$ & $\mathbf{7 . 8 1}$ & $\mathbf{3 . 9}$ & $\mathbf{1 . 9 5}$ & $\mathbf{0 . 9 7}$ & MIC \\
\hline $\begin{array}{l}\text { Aspergillus niger } \\
\text { ATCC 16404 }\end{array}$ & - & - & - & - & - & - & + & + & + & 7.81 \\
\hline $\begin{array}{l}\text { Candida albicans } \\
\text { TCC 10231 }\end{array}$ & - & - & - & - & - & - & - & + & + & 3.9
\end{tabular}

Tabla 5. Concentración inhibitoria mínima (CIM) del PE purificado. (-) Sin crecimiento; (+) Crecimiento. Concentración en $\mu \mathrm{g} / \mathrm{mL}$. Table 5. Minimum Inhibitory Concentration (MIC) of the purified PE. (-) No growth observed; (+) Growth observed. Concentration of extracts in $\mu \mathrm{g} / \mathrm{mL}$. 

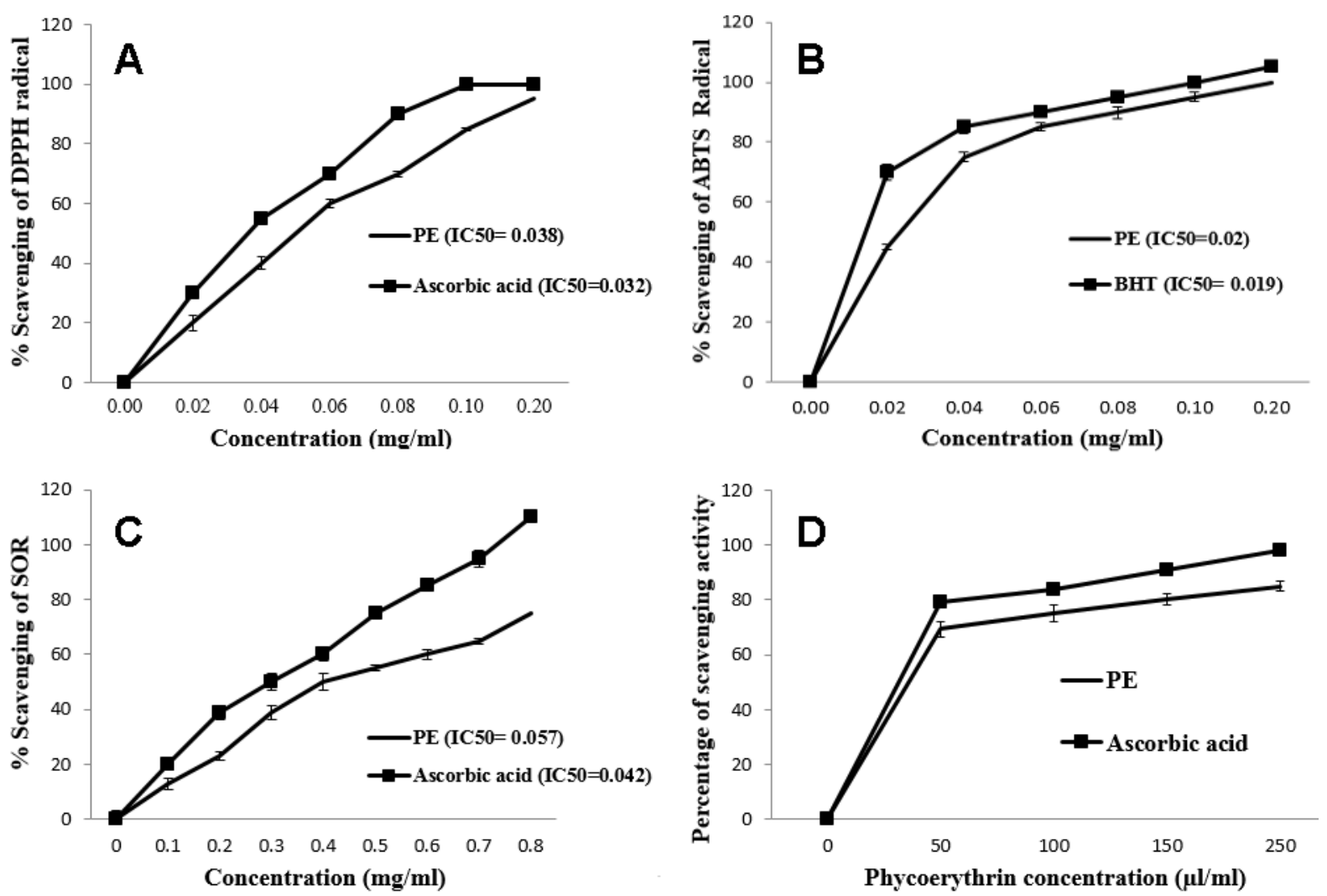

Figura 6. Potencial de eliminación de radicales libres de PE de Nostoc sp. A5. A: Método DPPH; B: Método ABTS; C: Método SOR; D: método del óxido nítrico.

Figure 6. Free radical scavenging potential of Nostoc sp. A5 PE. A: DPPH method; B: ABTS method; C: SOR method; D: nitric oxide method.

$0.02 \mathrm{mg} \mathrm{mL}^{-1}$ and $0.019 \mathrm{mg} \mathrm{mL}^{-1}$ for PE and standard BHT (butylated hydroxyl toluene), respectively (Fig. 6B). SOR anions were weak oxidants but generated powerful and harmful radicals. The $\mathrm{IC}_{50}$ for scavenging rate of $\mathrm{PE}$ and ascorbic acid were 0.057 and $0.042 \mathrm{mg} \mathrm{mL}^{-1}$, respectively (Fig. $6 \mathrm{C})$. In addition, the figure $6 \mathrm{D}$ illustrates the percentage inhibition of nitric oxide generation by $\mathrm{PE}$ in volumes of $10,25,50,100,150$ and $250 \mu \mathrm{L}$, which significantly scavenged $79 \%, 84 \%, 91 \%$ and $98 \%$ the nitric oxide radicals, respectively.

\section{Discussion}

Although a number of reports are available for PE purification and characterization from different cyanobacterial and red algal strains, exploitation and optimization of PE production from the genus Nostoc Vaucher ex Bornet \& Flahault are limited. PE has a great potential for pharmaceutical and food industry applications (Mishra et al. 2010, Tan et al. 2016). However, due to limited stability, its application has become a challenging endeavor. In order to find out a PE with high resis- tance and stability, the present investigation was carried out using Nostoc sp. A5 as a drought tolerant cyanobacterium. The strain was isolated from Cretaceous nodular chalk limestone and the region characterized by high light intensity as well as less than $0.5 \%$ of water. These unfavorable environmental conditions may enhance the stability and resistance of PE.

Many studies have reported that cyanobacteria were able to tolerate prolonged periods of drought (Simeunović et al. 2013). Furthermore, studies of pigment contents in cyanobacterial strains from different habitats may contribute to the understanding of cyanobacteria-specific acclimation processes and responses to environmental change conditions. Bioactive compounds isolated from cyanobacteria growing in unfavorable conditions maybe important for the production of biotechnologically valuable molecules, such as pigments (Johnson et al. 2014, Nowruzi et al. 2020a, 2020b, Nowruzi \& Blanco 2019). In this sense, two phycoerythrin-rich Synechococcus isolates shown different responses against light intensity (Postius 1998). In the present work, the absorption 
spectra indicated that the purified $\mathrm{PE}$ is of C-PE nature (Fig. 2 (step I to step IV)). Despite the occurrence of PE in Nostoc (Ranjitha \& Kaushik 2005) this is the first report of C-PE extracted from the genus Nostoc isolated from a limestone drought environment. The PE purity was investigated in a range of $\mathrm{pHs}$ with different buffers. Only acetate buffer (pH 5.1) resulted in high PE purity, indicating the complex chemical nature of biliproteins (PBPs). In fact, changes in $\mathrm{pH}$ values differentially affect the PBPs from different sources. R-PE from Polysiphonia urceolata (Lightfoot ex Dillwyn) Greville (Rhodophyta) showed purity at $\mathrm{pH} 3.5$ (Liu et al. 2009). At low $\mathrm{pH}$, denaturation or dissociation of PBPs into individual subunits may occur, and severe changes in $\mathrm{pH}$ values may disturb the electrostatic properties and hydrogen bonding involved in protein association leading to changes in chromophore structure (Liu et al. 2009). Variation in $\mathrm{pH}$ affects different processes such as solubility and bioavailability of nutrients, transport of substances across the cytoplasmic membranes, the activity of both intra and extracellular enzymes, photosynthetic electron transport and the osmotic potential of the cytoplasm.

Molecular weights of PE subunits may vary from organism to organism (Vásquez-Suárez et al. 2018). The SDS-PAGE analysis of the purified PE revealed two bands for Nostoc sp. A5 PE of $\sim 15 \mathrm{KDa}$ and $17 \mathrm{KDa}$ corresponding to $\alpha$ and $\beta$ subunits, respectively (Fig. 4). A $19.4 \mathrm{KDa}$ band were reported for PE in Nostoc muscorum by Ranjitha \& Kaushik (2005). Using preservative for PE grade is indispensable because it is highly sensitivity towards temperature, and the process should be commercially viable (Liu et al. 2009). Results from the present study showed that without adding additives, $\mathrm{PE}$ absorbance decreased as the temperature changed. At $25^{\circ} \mathrm{C}$ and $4{ }^{\circ} \mathrm{C}$ with the presence of glucose, PE stability was found to be better reached. Moreover, we have demonstrated that almost complete loss of C-PE content occurred at $40{ }^{\circ} \mathrm{C}$. However, Galland-Irmouli et al. (2000) have demonstrated the thermostability of R-PE from Palmaria palmate (L.) F. Weber \& D. Mohr (Rhodophyta) up to $60^{\circ} \mathrm{C}$.

Many studies have recorded the PE antimicrobial effects with moderate inhibition to $C$. albicans, A. niger, P. aeruginosa, E. coli, and Staphylococcus (Afreen \& Fatma 2018, Najdenski et al. 2013, Medina-Jartiz et al. 2011) similarly to observed in the present study.

The purified PE from Nostoc sp. A5 exhibited stability after 10 days, and this evidence may also be used for determining the resistance of pigment.

Phycoerythrin can be largely useful as food colorant (Sun et al. 2009). Although its security has been questioned, it is a strong antioxidant (Dufossé et al. 2005, Macedo et al. 2017, JerezMartel et al. 2017), which highlights its advantage. Solani et al. (2015) have recently reported the anti-oxidant based anti-ageing activity and anti-Alzheimer potential of $\mathrm{PE}$ isolated from Lyngbya sp. A09DM in wild type and transgenic Caenorhabditis elegans Maupas, 1900 (free-living nematode). However, little investigation about the effect of PE antioxidant activity is available in the literature.

Our results of antioxidant surveys suggest that PE has efficient scavenging effects $\left(\mathrm{IC}_{50}=0.038\right.$, 0.02 and $0.057 \mathrm{mg} \mathrm{mL}^{-1}$ for DPPH, ABTS and SOR anions, respectively) compared to ascorbic acid $\left(\mathrm{IC}_{50}=0.032\right.$ and 0.042$)$, and is a potent free radical scavenger acting as antioxidant molecule. Similarly, Afreen \& Fatma (2018), reported $\mathrm{IC}_{50}=0.043 \mathrm{mg} \mathrm{mL}^{-1}$ using the extract of Michrochaete Thuret ex Bornet \& Flahault for DPPH test. Furthermore, Valuta et al. (2015) demonstrated that extracts of Nostoc linckia Bornet ex Bornet \& Flahault (70 \% inhibition of ABTS radical) at $5 \mathrm{mg} \mathrm{L}^{-1}$ and ABTS radical scavenging capacity increased with the increasing phycobiliproteins concentration. Extracts of Nostoc sphaeroides Kützing ex Bornet \& Flahault showed considerable superoxide radical inhibiting activity according to Kuriakose (2007). The superoxide anion scavenging activity of the extract may be due to the direct scavenging of superoxide anion generated from photo illumination of riboflavin. Nitric oxide (NO) is an important chemical mediator generated by Staphylococcus Rosenbach y endothelial cells, macrophages, neurons, among others and involved in the regulation of various physiological processes. Excess concentration of $\mathrm{NO}$ is associated with several diseases, such as septic shock, atherosclerosis, ischemia-reperfusion, neurodegenerative disorders like Alzheimer's and Parkinson's diseases, cancer and diabetes (Wojcik et al. 2010). Oxygen reacts with the excess nitric oxide to generate nitrite and peroxynitrite anions, which act as free radicals. In the present study, the purified C-PE competed with oxygen to react with nitric oxide and inhi- 
bited the generation of the anions.

\section{Conclusions}

Nostoc sp. A5 is a limestone drought tolerant cyanobacterium with potential for bioprospecting uses. A stable C-PE produced by the strain A5 was successfully extract, purified, characterized and evaluated for in vitro stability under different temperatures, additives and $\mathrm{pH}$ conditions. Significant antioxidant activities of C-PE shown its feasibility for future applications as colorant in food industries and for pharmaceutical purposes. However, toxicological studies must be carried out for commercial production, since Nostoc is known as a toxing-producing genus. Furthermore, studies on its conformational behavior under high stress conditions will be extremely necessary to explore and enhance its molecular stability for industry applications. In addition, Nostoc's PE also shown ability for natural effective antibacterial and antifungal agents with significant stability up to 10 days. This highlights the need to explore microorganisms from unfavorable environmental conditions due to their potential for a wide variety of biological activities.

\section{References}

Afreen S \& Fatma T. 2018. Extraction, purification and characterization of phycoerythrin from Michrochaete and its biological activities. Biocatalysis and agricultural biotechnology 13: 84-89 https://doi.org/10. 1016/j.bcab.2017.11.012

Allen MM. 1968. Simple conditions for growth of unicellular blue-green algae on plates 1,2 . Journal of phycology 4(1):1-4 https://doi.org/10.1111/j.1529-8817. 1968.tb04667.x

Bennett A \& Bogorad L. 1973. Complementary chromatic adaptation in a filamentous blue-green alga. The Journal of cell biology 58(2): 419 https://doi.org/ 10.1083/jcb.58.2.419

Bryant DA, Guglielmi G, de Marsac NT, Castets AM \& Cohen-Bazire G. 1979. The structure of cyanobacterial phycobilisomes: a model. Archives of Microbiology 123(2): 113-127 https://doi.org/10.1007/BF00 446810.

Cadel-Six S, Dauga C, Castets AM, Rippka R, Bouchier C, Tandeau de Marsac N \& Welker M. 2008. Halogenase genes in nonribosomal peptide synthetase gene clusters of Microcystis (Cyanobacteria): Sporadic distribution and evolution. Molecular biology and evolution 25(9): 2031-2041 https://doi.org/10. 1093/molbev/msn150

Chakdar H \& Pabbi S. 2012. Extraction and purification of phycoerythrin from Anabaena variabilis (CCC
421). Phykos 42(1): 25-31.

Delgado-Vargas F \& Paredes-Lopez O, 2002. Natural colorants for food and nutraceutical uses. CRC press. https://doi.org/10.1201/9781420031713

Dufossé L, Galaup P, Yaron A, Arad SM, Blanc P, Murthy KNC \& Ravishankar GA. 2005. Microorganisms and microalgae as sources of pigments for food use: a scientific oddity or an industrial reality?. Trends in Food Science \& Technology 16(9): 389-406 https:// doi.org/10.1016/j.tifs.2005.02.006

Espinel-Ingroff A. 2007. Standardized disk diffusion method for yeasts. Clinical Microbiology Newsletter 29(13): 97-100 https://doi.org/10.1016/j.clinmicnews. 2007.06.001

Galland-Irmouli AV, Pons L, Lucon M, Villaume C, Mrabet NT, Guéant JL \& Fleurence J. 2000. One-step purification of R-phycoerythrin from the red macroalga Palmaria palmata using preparative polyacrylamide gel electrophoresis. Journal of Chromatography B: Biomedical Sciences and Applications 739(1): 117-123 https://doi.org/10.1016/S0378-4347 (99)00433-8

García-Falcón MS \& Simal-Gándara J. 2005. Determination of food dyes in soft drinks containing natural pigments by liquid chromatography with minimal clean-up. Food Control 16(3): 293-297 https://doi. org/10.1016/j.foodcont.2004.03.009

Gonzalez-Ramirez E, Andujar-Sanchez M, OrtizSalmeron E, Bacarizo J, Cuadri C, Mazzuca-Sobczuk T, . . . Martinez-Rodriguez S. 2014. Thermal and $\mathrm{pH}$ Stability of the B-Phycoerythrin from the Red Algae Porphyridium cruentum. Food Biophysics 9(2): 184-192 https://doi.org/10.1007/s11483-0149331-x

Jerez-Martel I, García-Poza S, Rodríguez-Martel G, Rico M, Afonso-Olivares C \& Gómez-Pinchetti JL. 2017. Phenolic profile and antioxidant activity of crude extracts from microalgae and cyanobacteria strains. Journal of Food Quality, https://doi.org/10. 1155/2017/2924508

Kamble SP, Gaikar RB, Padalia RB \& Shinde KD. 2013. Extraction and purification of C-phycocyanin from dry Spirulina powder and evaluating its antioxidant, anticoagulation and prevention of DNA damage activity. Journal of Applied Pharmaceutical Science 3(8): 149

Kesheri RM \& Sinha RP. 2011. Antioxidants as natural arsenal against multiple stresses in cyanobacteria. International Journal of Pharma and Bio Sciences 2(2) https://doi.org/10.7324/JAPS.2013.3826

Kim EY, Choi YH \& Nam TJ. 2018. Identification and antioxidant activity of synthetic peptides from phycobiliproteins of Pyropia yezoensis. International journal of molecular medicine 42(2):789-798 https://doi.org/ 10.3892/ijmm.2018.3650

Komárek J. 2013. Cyanoprokaryota. 3. Heterocytous genera. Süsswasserflora von Mitteleuropa. Bd 19 (3). Berlin: $1130 \mathrm{~S}$.

Kumar D, Dhar DW, Pabbi S, Kumar N \& Walia S. 2014. Extraction and purification of C-phycocyanin from Spirulina platensis (CCC540). Indian Journal of Plant Physiology 19(2): 184-188 https://doi.org/10. 1007/s40502-014-0094-7 
Kuriakose GC. 2007. Biomodulatory effects of Nostoc sphaeroides. Kerala, India: Mahatma Gandhi University. Doctoral Thesis.

Liu L, Jokela J, Wahlsten M, Nowruzi B, Permi P, Zhang YZ, Xhaard H, Fewer DP \& Sivonen K. 2014. Nostosins, trypsin inhibitors isolated from the terrestrial cyanobacterium Nostoc sp. strain FSN. Journal of natural products 77(8): 1784-1790 https://doi.org/10. 1021/np500106w

Liu LN, Su HN, Yan SG, Shao SM, Xie BB, Chen XL, Zhang $X Y, \ldots$ Zhang $Y Z$. 2009. Probing the $\mathrm{pH}$ sensitivity of R-phycoerythrin: Investigations of active conformational and functional variation. Biochimica et Biophysica Acta (BBA)-Bioenergetics 1787(7): 939-946. https://doi.org/10.1016/j.bbabio.2009.02.0 $\underline{18}$

Macedo D, Bertolin TE, Oro T, Backes LTH, Brás IC, Santos CN, . . . Outeiro TF. 2017. Phycocyanin protects against Alpha-Synuclein toxicity in yeast. Journal of Functional Foods 38: 553-560 https://doi. org/10.1016/j.jff.2017.09.044

Maurya SS, Maurya JN \& Pandey VD. 2014. Factors regulating phycobiliprotein production in cyanobacteria. International Journal of Current Microbiology and Applied Sciences 3(5): 764-771.

Medina-Jaritz NB, Perez-Solis DR, Ruiloba de Leon FSL \& Olvera-Ramirez R. 2011. Antimicrobial activity of aqueous and methanolic extracts from Arthrospira maxima. In: Science Against Microbial Pathogens: Communicating Current Research and Technological Advances (Mendez-Vilas A, ed.). Badajoz, Spain: Formatex, pp. 1267-1271

Mishra SK, Shrivastav A, Pancha I, Jain D \& Mishra S, 2010. Effect of preservatives for food grade C-Phycoerythrin, isolated from marine cyanobacteria Pseudanabaena sp. International journal of biological macromolecules 47(5): 597-602 https://doi.org/ 10.1016/j.ijbiomac.2010.08.005

Najdenski HM, Gigova LG, Iliev II, Pilarski PS, Lukavský J, Tsvetkova IV, Ninova MS \& Kussovski VK. 2013. Antibacterial and antifungal activities of selected microalgae and cyanobacteria. International journal of food science \& technology 48(7): 1533-1540 https:// doi.org/10.1111/ijfs.12122

Nowruzi B, Sarvari G \& Blanco S. 2020a. Applications of cyanobacteria in biomedicine. In Handbook of Algal Science, Technology and Medicine (Konur O, ed.) Amsterdam: Elsevier, pp. 441-454 https://doi.org/10. 1016/b978-0-12-818305-2.00028-0

Nowruzi B, Sarvari G \& Blanco S. 2020b. The cosmetic application of cyanobacterial secondary metabolites. Algal Research 49: 101959 https://doi.org/10.1016/ j.algal.2020.101959

Nowruzi B \& Blanco S. 2019. In silico identification and evolutionary analysis of candidate genes involved in the biosynthesis methylproline genes in cyanobacteria strains of Iran. Phytochemistry Letters 29: 199211. https://doi.org/10.1016/j.phytol.2018.12.011

Nowruzi B, Haghighat S, Fahimi H \& Mohammadi E. 2018a. Nostoc cyanobacteria species: a new and rich source of novel bioactive compounds with pharmaceutical potential. Journal of Pharmaceutical Health Services Research 9(1): 5-12. https://doi.org/

\subsection{1/jphs. 12202}

Nowruzi B, Blanco S \& Nejadsattari T. 2018b. Chemical and molecular evidences for the poisoning of a duck by anatoxin-a, nodularin and cryptophycin at the coast of Lake Shoormast (Mazandaran province, Iran). Algologia 28(4). https://doi.org/10.15407/alg 28.04.409

Nowruzi B, Khavari-Nejad RA, Sivonen K, Kazemi B, Najafi F \& Nejadsattari T. 2012. A gene expression study on strains of Nostoc (Cyanobacteria) revealing antimicrobial activity under mixotrophic conditions. African Journal of Biotechnology 11(51): 1129611308. https://doi.org/10.5897/AJB11.4129

Pandey VD, Pandey A \& Sharma V. 2013. Biotechnological applications of cyanobacterial phycobiliproteins. International Journal of Current Microbiology and Applied Sciences 2(9): 89-97.

Parmar A, Singh NK, Kaushal A, Sonawala S \& Madamwar D. 2011. Purification, characterization and comparison of phycoerythrins from three different marine cyanobacterial cultures. Bioresource technology 102(2): 1795-1802. https://doi.org/10.1016/j.biortech. 2010.09.025

Postius C, Kenter U, Wacker A, Ernst A \& Böger P. 1998. Light causes selection among two phycoerythrin-rich Synechococcus isolates from Lake Constance. FEMS microbiology ecology 25(2): 171-178. https://doi.org/10.1016/S0168-6496(97)00093-7

Rajabpour N, Nowruzi B \& Ghobeh M. 2019. Investigation of the toxicity, antioxidant and antimicrobial activities of some cyanobacterial strains isolated from different habitats. Acta Biologica Slovenica 62: 2

Ranjitha K \& Kaushik BD. 2005. Purification of phycobiliproteins from Nostoc muscorum. Journal of Scientific \& Industrial Research 64(5): 372-375.

Rastogi RP, Sonani RR \& Madamwar D. 2015. Physicochemical factors affecting the in vitro stability of phycobiliproteins from Phormidium rubidum A09DM. Bioresource Technology 190: 219-226 https://doi. org/10.1016/j.biortech.2015.04.090

Re R, Pellegrini N, Proteggente A, Pannala A, Yang M \& Rice-Evans C. 1999. Antioxidant activity applying an improved ABTS radical cation decolorization assay. Free radical biology and medicine 26(9-10): 12311237 https://doi.org/10.1016/S0891-5849(98)00315$\underline{3}$

Reis A, Mendes A, Lobo-Fernandes H, Empis JA \& Novais JM. 1998. Production, extraction and purification of phycobiliproteins from Nostoc sp. Bioresource technology 66(3): 181-187 https://doi.org/10. 1016/S0960-8524(98)00064-9

Román RB, Alvarez-Pez JM, Fernández FA \& Grima EM. 2002. Recovery of pure B-phycoerythrin from the microalga Porphyridium cruentum. Journal of $\mathrm{Bi}$ otechnology 93(1): 73-85 https://doi.org/10.1016/S0 168-1656(01)00385-6

Safavi M, Nowruzi B, Estalaki S \& Shokri M. 2019. Biological Activity of Methanol Extract from Nostoc sp. N42 and Fischerella sp. S29 Isolated from Aquatic and Terrestrial Ecosystems. Algologia 29(4): 421439 https://doi.org/10.15407/alg29.04.421

Sen AR \& Mandal PK. 2017. Use of natural antioxidants 
in muscle foods and their benefits in human health: An overview. International Journal of Meat Science 7(1): 1-5. https://doi.org/10.3923/ijmeat.2017.1.5

Seo YC, Choi WS, Park JH, Park JO, Jung KH \& Lee HY. 2013. Stable isolation of phycocyanin from Spirulina platensis associated with high-pressure extraction process. International journal of molecular sciences 14(1): 1778-1787 https://doi.org/10.3390/ ijms 14011778

Setyoningrum TM \& Nur MA. 2015. Optimization of Cphycocyanin production from $\mathrm{S}$. platensis cultivated on mixotrophic condition by using response surface methodology. Biocatalysis and Agricultural Biotechnology 4(4): 603-607 https://doi.org/10.1016/j.bcab. 2015.09 .008

Shanab SM, Mostafa SS, Shalaby EA \& Mahmoud GI. 2012. Aqueous extracts of microalgae exhibit antioxidant and anticancer activities. Asian Pacific Journal of Tropical Biomedicine 2(8): 608-615 https://doi.org/ 10.1016/S2221-1691(12)60106-3

Simeunović J, Bešlin K, Svirčev Z, Kovač D \& Babić O. 2013. Impact of nitrogen and drought on phycobiliprotein content in terrestrial cyanobacterial strains. Journal of Applied Phycology 25(2): 597-607 https:// doi.org/ 10.1007/s10811-012-9894-1

Sonani RR, Rastogi RP \& Madamwar D. 2015. Antioxidant potential of phycobiliproteins: Role in anti-aging research. Biochem Anal Biochem 4(172): 2161-1009 https://doi.org/10.4172/2161-1009.1000172

Stoyanov P, Moten D, Mladenov R, Dzhambazov B \& Teneva I. 2014. Phylogenetic relationships of some filamentous cyanoprokaryotic species. Evolutionary Bioinformatics, 10: EBO-S13748 https://doi.org/10. 1016/j.bcab.2015.09.00810.4137/EBO.S13748

Sun L, Wang S, Gong X, Zhao M, Fu X \& Wang L. 2009. Isolation, purification and characteristics of R-phycoerythrin from a marine macroalga Heterosiphonia japonica. Protein Expression and Purification 64(2): 146-154 https://doi.org/10.1016/j.pep.2008.09.013

Tan H, Gao S, Zhuang Y, Dong Y, Guan W, Zhang K, . . Cui J. 2016. R-Phycoerythrin induces SGC-7901 apoptosis by arresting cell cycle at $S$ phase. Marine drugs 14(9): 166 https://doi.org/10.3390/md140901 $\underline{66}$

Tchernov AA, Minkova KM, Houbavenska NB \& Kovacheva NG. 1999. Purification of phycobiliproteins from Nostoc sp. by aminohexyl-Sepharose chromatography. Journal of biotechnology 69(1): 69-73 https:/ doi.org/10.1016/S0168-1656(98)00206-5

Tiwari ON, Devi WI, Silvia C, Devi AT, Oinam G, Singh OA, . . Shamjetshabam M. 2015. Modulation of phycobiliprotein production in Nostoc muscorum through culture manipulation. Journal of Applied Biology \& Biotechnology 3(04): 11-16 https://doi.org/10. 7324/JABB.2015.3403

Tripathi SN, Kapoor S \& Shrivastava A. 2007. Extraction and purification of an unusual phycoerythrin in a terrestrial desiccation tolerant cyanobacterium Lyngbya arboricola. Journal of Applied Phycology 19(5): 441447 https://doi.org/10.1007/s10811-006-9151-6

Valuta A, Cepoi L, Rudi L, Bulhac I, Bourosh P \& Bologa O. 2015. Phycobiliprotein accumulation in cyanobacterium Nostoc linckia and modification of antioxidant activity. Analele Universitatii Din Oradea, Fascicula Biologie 22(1): 13-19

Vásquez-Suárez A, Lobos-González $F$, Cronshaw A, Sepúlveda-Ugarte J, Figueroa M, Dagnino-Leone J, Bunster M \& Martínez-Oyanedel J, 2018. The y33 subunit of R-phycoerythrin from Gracilaria chilensis has a typical double linked phycourobilin similar to $Y$ subunit. PloS one 13(4):, e0195656. https://doi.org/ 10.1371/journal.pone.0195656

Wada N, Sakamoto T \& Matsugo S. 2013. Multiple roles of photosynthetic and sunscreen pigments in cyanobacteria focusing on the oxidative stress. Metabolites, 3(2): 463-483 https://doi.org/10.3390/ metabo3020463

Wayne PA. 1999. National Committee for Clinical Laboratory Standards (NCCLS). Performance Standards for Antimicrobial Susceptibility Testing. 9th International Supplement, M100-S9.

Wikler MA, Cockerill FR, Craig WA, Dudley MN, Eliopolus GM, Hecht DW, . . . Zimmer BL. 2006. M7A7. Methods for dilution antimicrobial susceptibility tests for bacteria that grow aerobically; approved standard. Wayme, Pennsylvania: CLSI (NCCLS).

Wojcik M, Burzynska-Pedziwiatr I \& Wozniak LA. 2010. A review of natural and synthetic antioxidants important for health and longevity. Current Medicinal Chemistry 17(28): 3262-3288 https://doi.org/10. 2174/092986710792231950

Zhao M, Sun L, Sun S, Gong X, Fu X \& Chen M. 2013. The 42.1 and $53.7 \mathrm{kDa}$ bands in SDS-PAGE of Rphycoerythrin from Polysiphonia urceolata. International journal of biological macromolecules 60:405411 https://doi.org/10.1016/j.ijbiomac.2013.06.009 